\title{
Recycling by-products from coal-fired power stations into different construction materials
}

\author{
Yolanda Luna $\cdot$ Celia G. Arenas $\cdot$ Ana Cornejo $\cdot$ Carlos Leiva $\cdot$ \\ Luis F. Vilches $\cdot$ Constantino Fernández-Pereira
}

Received: 24 September 2013 / Accepted: 24 February 2014/Published online: 2 August 2014

(C) The Author(s) 2014. This article is published with open access at Springerlink.com

\begin{abstract}
The present investigation aims to analyse alternative uses of bottom ash and fly ash as part of construction materials for different applications: bottom ashbased ceramic bricks, pozzolanic material in the cement production, waste stabilisation/solidification of an electric arc furnace dust using ash-based geopolymers, and ashbased geopolymers used as hydraulic road binders. Different replacements of natural materials by different fly and/or bottom ashes have been studied in all the cases. This study has analysed various parameters influencing the manufacturing process, with the aim of reducing the energy consumption of these processes, as they have been, for example, the firing temperature of bricks and grind size of bottom ashes in cements. All materials are manufactured in a simple and economical way, in order not to increase the cost of the products, and the final products have been evaluated according to different European standards used in these applications, in order to assess their possible, actual technical feasibility. The results obtained in this study show that even higher ratios of replacement $(>40 \%)$ of ashes have properties similar to those commonly used.
\end{abstract}

Keywords Fly ash - Bottom ash · Bricks - Cement . Geopolymer · Waste stabilisation · Hydraulic road binder

Y. Luna - C. G. Arenas - A. Cornejo - C. Leiva ( $\square)$.

L. F. Vilches · C. Fernández-Pereira

Departamento de Ingeniería Química y Ambiental,

Escuela Técnica Superior de Ingenieros, Universidad de Sevilla,

Camino de los Descubrimientos s/n, 41092 Seville, Spain

e-mail: cleiva@us.es

\author{
Abbreviations \\ BB Bottom ashes from the combustion of coal \\ BC Bottom ashes from the co-combustion of coal \\ and pet-coke \\ EAFD Electric arc furnace dust \\ EULFD European Landfill Directive \\ FA Fly ash from the combustion of coal \\ $\mathrm{H} \quad$ Hazardous waste \\ HRB Hydraulic road binder \\ I Inert waste \\ LOI Loss on ignition \\ NaSil Sodium silicate \\ NC Natural clay \\ $\mathrm{NH} \quad$ Non-hazardous waste \\ PCI Portland cement type I \\ WR Mixing water requirements
}

\section{Introduction}

In the European Union of first 15 member states the production was about 52 million tonnes in 2009 , and in the larger EU of 27 member states the total production is estimated to be about 100 million tonnes [1]. Governments should favour more the use of secondary raw materials. Legislation and rules to increase such use are being improved. In several cases the minerals from coal bring extra quality and higher performance compared to the prime raw materials which are being replaced. Applying minerals from coal adds a green label to construction due to energy savings and preservation of natural resources.

Fly ash, which is obtained by electrostatic or mechanical precipitation of dust-like particles from the flue gas, represents the greatest proportion of total coal combustion byproducts. Within the EU, the utilisation for fly ash in the 
construction industry is currently around $44 \%$ and for bottom ash around $45 \%$ [1]. Fly/bottom ashes may be used as a replacement for naturally occurring resources and therefore offer environmental benefits by avoiding the need to quarry or mine these resources. The recycling of fly and bottom ashes also help to reduce energy demand as well as emissions to atmosphere, for example $\mathrm{CO}_{2}$, which result from the manufacturing process of the products which are replaced.

On the other hand, the construction industry might not be considered an environmentally friendly activity since it depletes the supply of natural resources and generates a large amount of waste. This waste has to be properly managed in order not to pollute and deteriorate the urban and rural landscape. Consequently, the growth of the construction industry is restricted by the environment source and sinks' limits. The source limits refer to the finite capacity of the environment to provide resources, both renewable and non-renewable, whereas the sinks' limits refer to the capacity of the environment to assimilate the waste caused by the economic growth and development.

From an environmental and economic point of view, the bottom ash and fly ash are considered valuable raw materials which make their recycling appropriate and convenient in construction applications. In order to tackle this task, the present investigation aims to analyse alternative uses of bottom ash and fly ash as part of construction materials for different applications: bottom ash-based ceramic bricks, bottom ash as pozzolanic material in the cement production, waste stabilisation/solidification of hazardous wastes using ash-based geopolymers, and ashbased geopolymers used as hydraulic road binders (HRB).

The first stage has been to analyse the potential use of bottom ash as a raw material by replacing natural clay (NC) to make fired bricks. The effect of the addition of two bottom ashes (BC and BB) was analysed, through the variation of different bottom ash/clay ratios. The influence of the firing temperature $\left(900-1,100{ }^{\circ} \mathrm{C}\right)$ on the properties of fired bricks was also investigated.

The second stage of the study has been to determine and evaluate the potential use of bottom ash as an additive in the production of cement. The objective has been to evaluate the pozzolanic properties of bottom ash as an additive in cement, as it has been demonstrated in the case of fly ash for many years. Fly ash and bottom ash are generated together in power plants and then, in most of the cases, both ashes have quite similar chemical composition. Therefore, the potential recycling of bottom ash has been analysed as a substitute for fly ash in cement production. As long as there are no standards for the addition of bottom ash in cement, criteria stated for fly ashes in the EN 197-1 [2] have been followed in order to assess the potential application of bottom ash in cement production. This normative establishes composition, specification, and conformity criteria for common cements.

The term "geopolymer" describes the structures consisting of a polymeric $\mathrm{Si}-\mathrm{O}-\mathrm{Al}$ framework, similar to that found in zeolites [3]. Geopolymers can be used as binders in stabilisation/solidification systems of waste containing heavy metals. In the immobilization of toxic metals field, geopolymer systems behave similarly to cement binders, in terms of encapsulation. However, geopolymers have improved the chemical and physical properties of cement binders, such as structural integrity, low permeability, high compressive strength and durability [4, 5]. The stabilisation/solidification of an EAFD containing hazardous metals such as $\mathrm{Pb}, \mathrm{Cd}, \mathrm{Cr}$ or $\mathrm{Zn}$ by using geopolymerization technology is described in the third stage. The geopolymers have been manufactured using other wastes such as fly ash and bottom ash.

The last stage focuses on the results concerning the use of geopolymers as hydraulic binder used as base course in road structures (HRB). An HRB is a factory-produced hydraulic binder supplied ready for use, having properties specifically suitable for treatment of material for bases, sub-bases and capping layers as well as earthworks in road, railway and airport. $\mathrm{HRB}$ consists of a powder made from a blend of different constituents and statistically homogeneous in composition. A high degree of uniform unity is all properties shall be obtained through continuous mass production process. The vast majority of HRBs include clinker in their composition, the production of which consumes a lot of energy and is responsible for significant $\mathrm{CO}_{2}$ emissions. The aim of this work is to find a replacement of these cement products by others without $\mathrm{CO}_{2}$ emissions. This substitute must be competitive in terms of their properties as binder.

\section{Methods}

Two different bottom ashes, one from the co-combustion of coal and pet-coke (BC) and the other from the traditional coal combustion (BB) were used in this study, as well as fly ash from the traditional coal combustion (FA). A Portland cement type I (PCI) and NC were used as binders. An electric arc furnace dust (EAFD), a powder derived from the particulate matter collector systems in the production of carbon steels, was used as hazardous waste in the waste stabilisation/solidification application. The chemical composition and size distribution of different materials used in this work is showed in Table 1 and Fig. 1 respectively.

The geopolymers used in this work were prepared with an activating solution consisting in sodium silicate, NaSil [25.5-28.5 of $\mathrm{SiO}_{2}(\mathrm{wt} \%)$ and 7.5-8.5 of $\mathrm{Na}_{2} \mathrm{O}(\mathrm{wt} \%)$, and sodium hydroxide $(10 \mathrm{M})$. 
Table 1 Chemical composition of the raw materials used in the investigation

\begin{tabular}{lrrllll}
\hline Parameter & \multicolumn{1}{l}{$\mathrm{BC}$} & \multicolumn{1}{l}{$\mathrm{BB}$} & $\mathrm{FA}$ & $\mathrm{PCI}$ & \multicolumn{1}{l}{ NC } & EAFD \\
\hline $\mathrm{SiO}_{2}$ & 55.32 & 64.45 & 59.0 & 23.65 & 77.56 & 6.21 \\
$\mathrm{Al}_{2} \mathrm{O}_{3}$ & 25.14 & 15.89 & 24.9 & 4.79 & 11.25 & 15.90 \\
$\mathrm{Fe}_{2} \mathrm{O}_{3}$ & 9.23 & 7.77 & 7.14 & 2.61 & 3.26 & 7.77 \\
$\mathrm{MgO}$ & 1.84 & 2.45 & 1.94 & 1.69 & 1.18 & 3.05 \\
$\mathrm{CaO}$ & 2.37 & 3.92 & 2.24 & 66.63 & 1.47 & 8.60 \\
$\mathrm{Na}_{2} \mathrm{O}$ & 0.66 & 0.89 & 0.86 & 0.46 & 0.19 & 1.13 \\
$\mathrm{~K}_{2} \mathrm{O}$ & 3.72 & 1.60 & 3.85 & 0.17 & 3.55 & 1.60 \\
$\mathrm{SO}_{3}$ & 0.03 & $<0.01$ & - & - & $<0.01$ & - \\
$\mathrm{P}_{2} \mathrm{O}_{5}$ & 0.25 & $<0.01$ & - & - & $<0.01$ & - \\
$\left.\mathrm{LOI}^{(750}{ }^{\circ} \mathrm{C}\right)$ & 1.07 & 11.86 & 5.26 & 1.1 & 3.37 & 11.9 \\
$\mathrm{Specific} \mathrm{gravity}^{2}$ & 2.2 & 2.0 & - & 3.2 & 2.32 & - \\
$\left(\mathrm{g} / \mathrm{cm}^{3}\right)$ & & & & & & \\
\hline
\end{tabular}

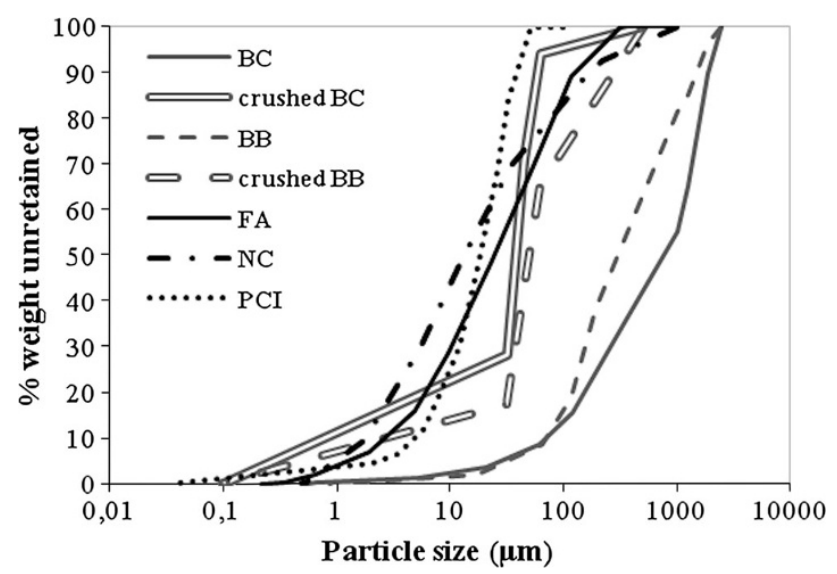

Fig. 1 Size distribution of raw $\mathrm{BC}$ and $\mathrm{BB}$, crushed $\mathrm{BC}$ and $\mathrm{BB}, \mathrm{FA}$, PCI and NC

The density $(\rho)$ of the panels was measured by weight and volume (dimensions) measurements [6]. The water absorption $(A)$ was measured according to EN 12859 [7]. The mass of the panel was measured before its immersion in water $(M 1)$, the temperature of the water ranging between 21 and $25{ }^{\circ} \mathrm{C}$. After $120 \mathrm{~min}$ the panel was taken out from water, drained for $5 \mathrm{~min}$, and its mass was measured again $(M 2)$. The water absorption value $(A)$ is calculated by:

$A=\frac{M 2-M 1}{M 1} \times 100$

The humidity $(M)$ was measured according to [8]. The mass of the panel was measured at ambient temperature (M1) and after heating at $40{ }^{\circ} \mathrm{C}$ until a constant mass (M3) was reached, the value of moisture content $(M)$ is calculated by:

$M=\frac{M 3-M 1}{M 1} \times 100$
The initial setting time has been measured using a Vicat apparatus [9]. The the volumetric expansion is determined using Le Chatelier's apparatus [9]. The volumetric expansion affects the potential application of the material as a construction product since volume changes with respect to other products can generate construction defects.

The compressive [10] and flexural [11] strengths of the samples were evaluated using a compressive testing machine (Suzpecar, MEM-102/50 t). The compressive strength tests were performed on 40-mm-high, 33-mmdiameter cylinders and the loading rate was $2 \mathrm{~mm} \mathrm{~min}^{-1}$ [10]. The flexural strength tests were done on 14-cm-high prismatic test probes with a base of $4 \times 4 \mathrm{~cm}^{2}$. The flexural test was carried out in three-point bending up to failure at the loading rate of $2 \mathrm{~mm} \mathrm{~min}{ }^{-1}$, with a span length of $100 \mathrm{~mm}[11]$.

An environmental study has been carried out to characterise the geopolymers more completely in order to better evaluate its possible uses. The study involved subjecting the material to the EN12457-4 leaching test [12], at a liquid to solid ratio of $10 \mathrm{~L} / \mathrm{kg}$, as well as subjecting the product to one of the most commonly used leaching tests in the waste management field in Europe. Toxicity characteristic leaching procedure method no. 1311 (TCLP) [13] test consist of stirring the granular material $(<9 \mathrm{~mm})$, using an acetic acid solution at $\mathrm{pH} 4.93 \pm 0.05$ with a liquid/solid ratio of 20 for $18 \mathrm{~h}$. Leachate metal analysis was carried out using Atomic absorption spectrophotometry and inductively coupled plasma techniques.

\section{Results and discussion}

Effect of coal bottom ash addition and firing temperature on ceramic bricks properties

The chemical composition of $\mathrm{BC}, \mathrm{BB}$ and $\mathrm{NC}$ was shown in Table 1. The content of silica, alumina and magnesium oxide is strongly related to the sintering process and the subsequent forming of a tough ceramic matrix, when the sintering temperature has been reached [14]. The materials used presented a similar content of these chemical compounds. The silica contributes to improve the plasticity, hardness and mechanical properties of the mixtures [15] and the clay has a higher content of silica than bottom ashes. The high loss of ignition (LOI) of BB will make the specimens based on this bottom ash have a more porous internal structure. Regarding the specific density of the materials used, clay presents the greatest specific gravity, followed by $\mathrm{BC}$ and $\mathrm{BB}$. The particle size distribution of the raw materials was shown in Fig. 1. In order to improve the homogeneity of the bottom ash/clay mixtures, the bottom ashes were sieved to remove particles larger 
than $2.5 \mathrm{~mm}$. Particles of clay are much finer than the bottom ashes, as evidenced by the average particle size $D_{50}$ of $13.2,234.9$ and $771.2 \mu \mathrm{m}$ of $\mathrm{NC}, \mathrm{BB}$ and $\mathrm{BC}$ respectively. Therefore, the different particle size of the bottom ashes and clay causes a lack of homogeneity in the mixes, decreasing the structural properties of the final firing product.

In order to study the replacement of clay by bottom ash in the properties of ceramic bricks, different bottom ash/ clay ratios have been tested. The composition of the mixtures is shown in Table 2, as well as the mixing water requirements (WR). It is important to notice that as the proportion of bottom ash increases the mixtures required more water due to the replacement of clay, with greater

Table 2 Mix proportions (\% weight) of ceramic bricks

\begin{tabular}{lcccl}
\hline Nomenclature & NC $(\%)$ & BC $(\%)$ & BB $(\%)$ & WR $(\%)$ \\
\hline NC & 100 & - & - & 23 \\
BC40 & 60 & 40 & - & 27 \\
BC60 & 40 & 60 & - & 30 \\
BB40 & 60 & - & 40 & 27 \\
BB60 & 40 & - & 30 & 30 \\
\hline
\end{tabular}

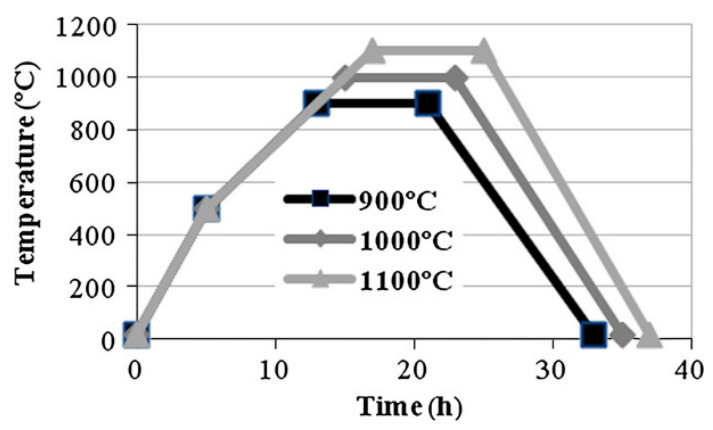

Fig. 2 Heating programme content of silica than bottom ash, which provides plasticity to the mix. The specimens, cylinders $32.5 \mathrm{~mm}$ diameter and $50 \mathrm{~mm}$ length, were manufactured by compressing at $10 \mathrm{MPa}$. The compressing pressure was chosen based on previous results [15], and similar to those found in the bibliography [16]. The specimens were immediately removed from the moulds and dried at $60{ }^{\circ} \mathrm{C}$ until constant weight was achieved. Then, they were fired in an electric furnace according to the designed heating programme shown in Fig. 2. This heating programme is based on similar programmes found in the literature [17]. The heating rate was $100{ }^{\circ} \mathrm{C} / \mathrm{h}$ below $500{ }^{\circ} \mathrm{C}$, then $50{ }^{\circ} \mathrm{C} / \mathrm{h}$ from $500{ }^{\circ} \mathrm{C}$ to the highest temperature selected, keeping it $8 \mathrm{~h}$ at that temperature. This heating programme ensures that all the material reaches the firing temperature selected. Three different firing temperatures $(900,1,000$ and $1,100{ }^{\circ} \mathrm{C}$ ) were studied in order to analyse the effect on the properties of the final products.

The bottom ash-based ceramic materials studied were characterised by measuring the bulk density, water absorption and compressive strength, and their results have been compared to a control mixture based solely on clay.

The effect of the ratio bottom ash/clay and the firing temperature on the properties of ceramic bricks is presented in Figs. 3, 4 and 5. As the firing temperature was increased, the products showed a greater density in all the cases due to the increase in the sintering grade which makes the porosity decrease as well [18]. The products were less dense when the proportion of bottom ash added in the mixtures was higher, because of the lower specific gravity of the bottom ash than that of the NC. However, at $1,000{ }^{\circ} \mathrm{C}$, compositions with $40 \%$ of bottom ash showed greater density than the control mixture, and those with $60 \%$ of bottom ash were similar. Probably it is because the sintering process took place at that temperature and this effect prevailed over the specific gravity [18]. Comparing both bottom ashes, results are very similar to each other for
Fig. 3 Variation of the density with the proportion of bottom ash and firing temperature

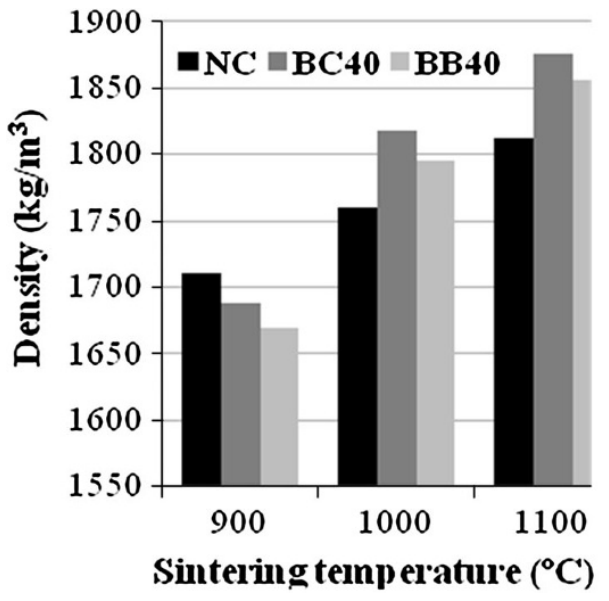


Fig. 4 Variation of water absorption with the proportion of bottom ash and firing temperature
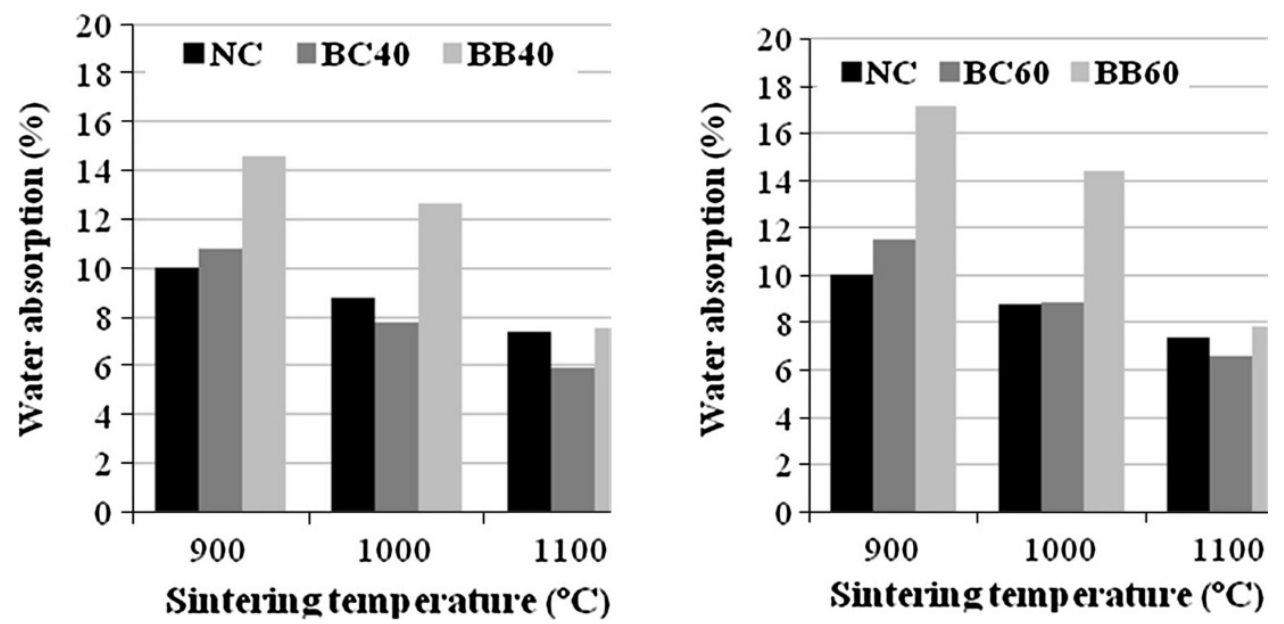

Fig. 5 Variation of compressive strength with the proportion of bottom ash and firing temperature

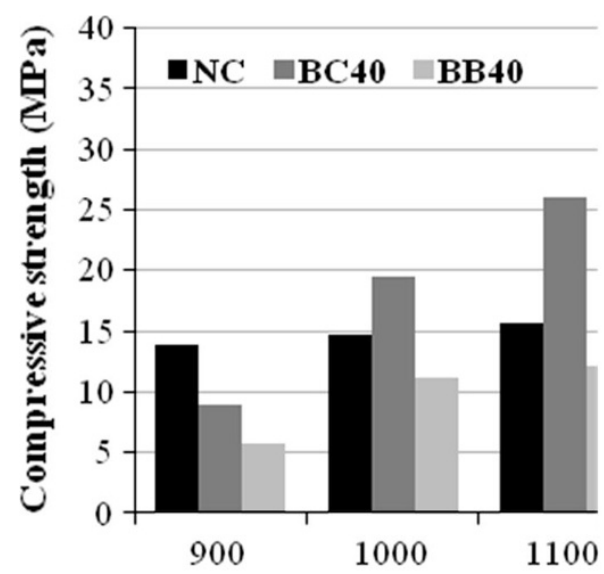

Sintering temp erature $\left({ }^{\circ} \mathrm{C}\right)$

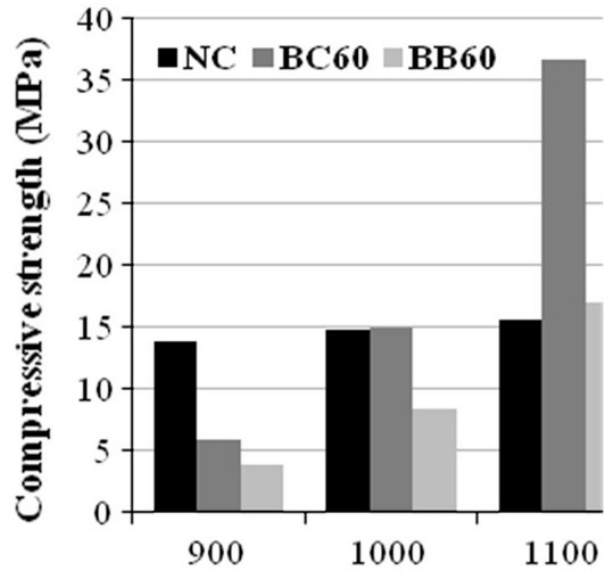

Sintering temp erature $\left({ }^{\circ} \mathrm{C}\right)$ all the compositions, though mixtures of BB presented less density than $\mathrm{BC}$ compositions, probably due to the lower specific gravity and higher LOI. Generally, a good quality brick possesses a density in the range of $1,700-2,000 \mathrm{~kg} /$ $\mathrm{m}^{3}$ [19], so all the compositions at 1,000 and $1,100{ }^{\circ} \mathrm{C}$ presented appropriate values. The water absorption is a key factor affecting the durability of the bricks and it is also a measure of the open porosity of the products. It showed an opposite tendency to the density. An increase in the firing temperature produced a decrease in the water absorbed due to the sintering process, which decreases the porosity of the material. Although the water absorption increased with the content of bottom ash, BC40 and BC60 fired at 1,000 and $1,100{ }^{\circ} \mathrm{C}$ showed less water absorption than the control specimen. However, compositions BB40 and BB60 reached similar water absorption to $\mathrm{NC}$ only at $1,100{ }^{\circ} \mathrm{C}$. Probably the sintering temperature has been achieved at $1,000{ }^{\circ} \mathrm{C}$ for $\mathrm{BC}$ and $1,100{ }^{\circ} \mathrm{C}$ for $\mathrm{BB}$, highly decreasing the porosity and the water absorption of the material compared to the mixture based solely on clay. BB showed greater water absorption than $\mathrm{BC}$, possibly because the higher LOI of this ash which makes the final product to have a more porous internal structure [20]. Regarding the compressive strength, its variation is strongly related to the variation of the density and the water absorption. As the firing temperature was higher, the compressive strength increased due to the formation of more vitrified crystalline phases at higher temperatures, which merge and mix with the clay body, forming a less porous material, more dense and resilient [21]. As it happened with the other properties studied, when the sintering temperature was reached $\left(1,000{ }^{\circ} \mathrm{C}\right.$ for $\mathrm{BC}, 1,100{ }^{\circ} \mathrm{C}$ for $\left.\mathrm{BB}\right)$, the mechanical strength increased considerably comparing to the control mixture. Compositions of $\mathrm{BC}$ presented higher compressive strength than $\mathrm{BB}$, probably due to the higher LOI of $\mathrm{BB}$ which increases the total porosity of the structure.

Use of crushed coal bottom ash as a pozzolanic material in cement production

The main difference between $\mathrm{BC}$ and $\mathrm{BB}$ is found in their morphology and grain size. In this study, bottom ashes 
were provided crushed by both suppliers, so their grain size would be similar to fly ash.

The chemical composition of bottom ashes are presented in Table 1, and they are compared with the chemical specifications for fly ashes in cement according to EN 450-1 [22]. Bottom ash can be classified regarding the LOI. According to the normative, the LOI must be within the categories $0-5,2-7$ or $4-9 \%$ by weight. BC belongs to the first category while BB is out of the limits stated, with a quite high LOI. High LOI is believed to interfere with the hydration reactions, as well as reducing the workability and increasing the water demand when used in concrete, affecting the final strength and durability of the product [23]. The content of $\mathrm{CaO}$ is usually low in co-combustion fly ash [24], as well as in both types of this bottom ash. The normative sets a limit of $10 \%$ by weight in the content of $\mathrm{CaO}$, which is accomplished by both bottom ashes. The content of $\mathrm{SiO}_{2}+\mathrm{Al}_{2} \mathrm{O}_{3}+\mathrm{Fe}_{2} \mathrm{O}_{3}$ is higher than the $70 \%$ by weight. These components take part in the pozzolanic reactions with $\mathrm{Ca}(\mathrm{OH})_{2}$ present in the hydration of clinker [25]. High content of $\mathrm{MgO}$ is detrimental to the soundness of the mortar [26], in $\mathrm{BC}$ and $\mathrm{BB}$ it is lower than the limit of $10 \%$ stated by the normative. The content of $\mathrm{SO}_{3}$ is limited to $3 \%$ by weight because it causes the chemical attack by the reaction with $\mathrm{Ca}(\mathrm{OH})_{2}$ [27]. The content of $\mathrm{SO}_{3}$ is under the limit in both bottom ashes.

EN 197-1 Standard defines the fineness as the \% weight of the ash which is retained by a sieve of $40 \mu \mathrm{m}$. According to the regulation, the fineness must be within $30-10 \%$. The particle size distribution curves of $\mathrm{BC}$ and $\mathrm{BB}$ are presented in Fig. 1. From the figure, taking into account that which is represented is the $\%$ by weight unretained, the fineness of $\mathrm{BC}$ is around $35 \%$. For BB the fineness is higher, around $65 \%$ which will be out of the range required. The particle size is important because lower size implies higher specific surface, where the reactions take place.

Table 3 presents the mix proportions tested. From a composition with only PCI, it has gradually been replaced by bottom ash in different proportions, trying to keep similar ratios to those of Portland cement type II $(\mathrm{CPI}+$ fly ash) and type IV (CPI + pozzolanic material). The mix water ratio has remained nearly the same for all the compositions, keeping a water/solid ratio around 0.4. The samples were cured in water $\left(20^{\circ} \mathrm{C}\right)$ for 27 days.

The aim of this study has been to analyse the influence of adding bottom ash on the physical and mechanical properties of the final product: density, initial setting time, soundness, compressive and flexural strength. Besides that, the influence of the type of bottom ash, with quite different LOI, has been analysed.

The density of mixes with bottom ash, Fig. 6, was under the density of E0, represented by a dotted line, due to the
Table 3 Mix proportions (\% weight) of bottom ash-based cement

\begin{tabular}{lccc}
\hline Nomenclature & PCI $(\%)$ & BC $(\%)$ & BB $(\%)$ \\
\hline E0 & 100 & - & - \\
BC5 & 95 & 5 & - \\
BC15 & 85 & 15 & - \\
BC25 & 75 & 25 & - \\
BC35 & 65 & 35 & - \\
BB5 & 95 & - & 5 \\
BB15 & 85 & - & 15 \\
BB25 & 75 & - & 25 \\
BB35 & 65 & - & 35 \\
\hline
\end{tabular}

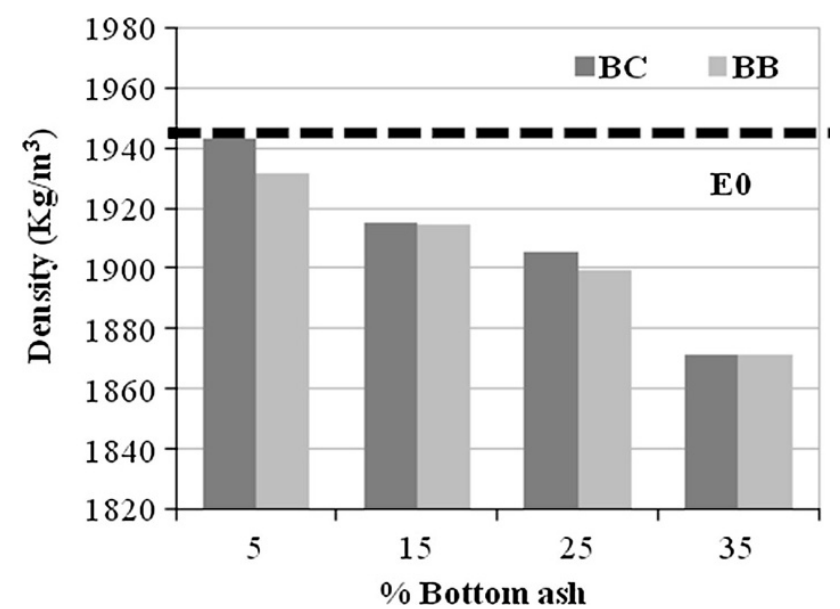

Fig. 6 Density of samples of bottom ash-based cement

lower specific density of bottom ashes than PCI. Then, when PCI was gradually replaced by bottom ash, the density of the samples decreased gradually as well. Comparing the density of the mixes made from different bottom ash, compositions of $\mathrm{BC}$ were slightly denser than those of $\mathrm{BB}$, probably as a result of greater specific density of $\mathrm{BC}$ compared to $\mathrm{BB}$. Besides that, high LOI is proved that increases the total effective porosity of the mortars [28] as well as greater particle size, thus the density of mixes with $\mathrm{BB}$ has to be lower.

The variation in the compressive strength at 28 days with the proportion of bottom ash added in the compositions is shown in Fig. 7. In general, as the proportion of bottom ash increased, the compressive strength of the samples decreased. However, for low additions, such as 5 and $15 \%$, the compressive strength measured was above the one tested for E0. A slight increase in the content of bottom ash improves the compressive strength because of the pozzolanic activity of the bottom ash [20]. On the other hand, when the cement is replaced in greater proportions, the reduction of $\mathrm{CaO}$ content is predominant, causing a decrease in the resistance to compressive stress. This 
Fig. 7 Compressive and flexural strength of samples with bottom ash

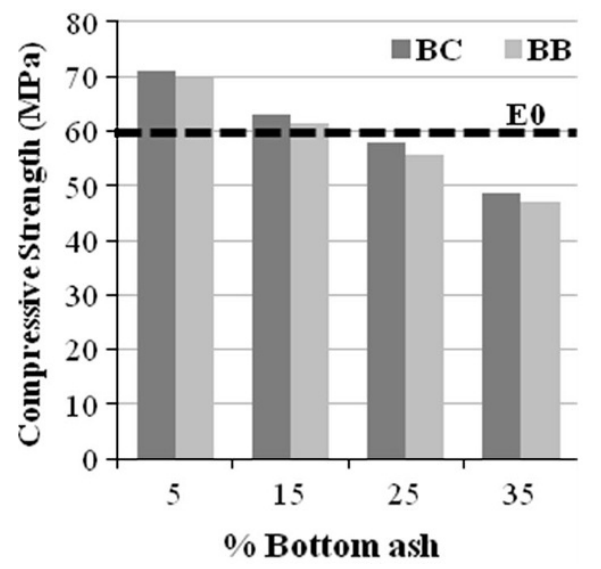

behaviour was in accordance with previous authors studies $[26,27]$. Comparing both bottom ashes, no significant differences were noticed regarding the mechanical resistance, though compositions with high proportion of $\mathrm{BB}$ showed lower compressive strength than $\mathrm{BC}$ mixtures. This could be due to the fact that the high LOI of $\mathrm{BB}$ ashes increased the porosity of the structure as well as greater particle size, as stated previously. Higher porosity leads to lower compressive strength [28]. The European standard EN 197-1 [2] defines the mechanical requirements for commercial cements. According to the compressive strength measured at 28 days, cements are classified as class $32.5,42.5$, and 52.5. Up to $15 \%$ of bottom ash additions, mixtures would be determined as class 52.5. Then, mixtures with $25 \%$ of bottom ash would be classified as class 42.5 , whereas those with $35 \%$ of bottom ash would be class 32.5 . Therefore, bottom ashes could be included as a main constituent of common cements according to the mentioned standard.

Bottom ash compositions displayed a similar trend in the development of flexural strength than the compressive strength. Results for 28-day samples are shown in Fig. 7. As the content of bottom ash was higher, the flexural strength decreased. For low additions of bottom ash, as it happened when testing the compressive strength, the flexural strength was similar to that for the control mixture E0 [30]. Comparing both bottom ashes, the results showed that $\mathrm{BB}$ had worse behaviour to blend stresses than $\mathrm{BC}$ due to higher particle size and LOI of $\mathrm{BB}$ that make the mortar more porous [31]. No requirements regarding the flexural strength are established by the European standard EN 197-1.

The initial setting time of the different compositions is shown in Table 4. As the proportion of bottom ash increased, the initial setting time went up. This fact is in accordance with Spanish regulation UNE 83414 EX [32], for additives in concrete, where it is stated that adding fly ash to concrete composition increases the initial setting time. The initial setting time is limited by EN 197-1 [2]
Table 4 Initial setting time and volumetric expansion of bottom ashbased cements

\begin{tabular}{lll}
\hline Specimen & $\begin{array}{l}\text { Initial setting } \\
\text { time }(\mathrm{min})\end{array}$ & $\begin{array}{l}\text { Volumetric } \\
\text { expansion }(\mathrm{mm})\end{array}$ \\
\hline E0 & 160 & 1.80 \\
BC5 & 200 & 1.55 \\
BC15 & 255 & 1.55 \\
BC25 & 300 & 1.80 \\
BC35 & 340 & 1.70 \\
BB5 & 195 & 1.55 \\
BB15 & 240 & 1.65 \\
BB25 & 290 & 1.60 \\
BB35 & 355 & 1.70 \\
\hline
\end{tabular}

according to the classification made by the compressive strength results. Cements class 52.5 must have initial setting times above $45 \mathrm{~min}$, which is accomplished by the specimens with contents of $5-15 \%$ of bottom ash. For cements class 42.5 , the initial setting time must be greater than 60 min, thus mixtures with $25 \%$ of bottom ash are within the limit. Lastly, cements class 32.5 are required to have initial setting times above $75 \mathrm{~min}$, which corresponds to samples with $35 \%$ of bottom ash.

The volume stability affects the potential application of the material as a construction product since volume changes could cause structure failures. The volumetric expansion of the samples is limited to $10 \mathrm{~mm}$ according to EN 197-1 [2]. In Table 4 are shown the results obtained for bottom ash-based mortars. In all the compositions, the volumetric expansion was below the limit reported by the regulation. There is no variation in the volume stability of the mortars with the proportion of bottom ash. It could be due to the fact that the content of $\mathrm{MgO}, \mathrm{SO}_{3}$ and $\mathrm{CaO}$ is very low in both bottom ashes. High contents of these compounds are related to the volumetric expansion of cement pastes as they react producing potentially expansive new compounds [29, 30]. 
Waste stabilisation/solidification of an electric arc furnace dust using bottom and fly ash-based geopolymers

Different fly ash/bottom ash ratios have been used to elaborate the geopolymer. Mixtures of EAFD waste with

Table 5 Leaching results of BB, FA and EAFD according to EN 12457-4 and limits of EULFD

\begin{tabular}{lcccllr}
\hline & \multirow{2}{*}{$\begin{array}{l}\mathrm{BB} \\
(\mathrm{mg} / \mathrm{kg})\end{array}$} & $\begin{array}{l}\text { FA } \\
(\mathrm{mg} / \mathrm{kg})\end{array}$ & $\begin{array}{l}\text { EAFD } \\
(\mathrm{mg} / \mathrm{kg})\end{array}$ & \multicolumn{2}{l}{ Limits EULFD $(\mathrm{mg} / \mathrm{kg})$} \\
\cline { 5 - 7 } \cline { 5 - 6 } & & & & $\mathrm{I}$ & $\mathrm{NH}$ & $\mathrm{H}$ \\
\hline $\mathrm{Hg}$ & $<0.01$ & $<0.01$ & $<0.50$ & 0.01 & 0.2 & 2 \\
$\mathrm{Se}$ & $<0.05$ & $<0.04$ & 1.69 & 0.1 & 0.5 & 7 \\
$\mathrm{~Pb}$ & $<0.06$ & $<0.03$ & 6.23 & 0.5 & 10 & 50 \\
$\mathrm{Ba}$ & 0.63 & 0.31 & 1.74 & 20 & 100 & 300 \\
$\mathrm{Cd}$ & $<0.01$ & $<0.003$ & 0.30 & 0.04 & 1 & 5 \\
$\mathrm{Sb}$ & $<0.05$ & $<0.02$ & 1.51 & 0.06 & 0.7 & 5 \\
$\mathrm{Cr}$ & $<0.01$ & 0.152 & 30.1 & 0.5 & 10 & 70 \\
$\mathrm{As}$ & $<0.03$ & $<0.03$ & 11.2 & 0.5 & 2 & 25 \\
$\mathrm{Mo}$ & 0.97 & $<0.01$ & 42.5 & 0.5 & 10 & 30 \\
$\mathrm{Ni}$ & $<0.01$ & $<0.01$ & $<0.10$ & 0.4 & 10 & 40 \\
$\mathrm{Zn}$ & 0.38 & $<0.001$ & 7.21 & 4 & 50 & 200 \\
$\mathrm{Cu}$ & $<0.01$ & $<0.003$ & $<5.00$ & 2 & 50 & 10 \\
\hline
\end{tabular}

Table 6 Compositions of different geopolymer pastes

\begin{tabular}{lllllll}
\hline & FA (\%) & BB (\%) & $\begin{array}{l}\text { EAFD } \\
(\%)\end{array}$ & $\begin{array}{l}\text { NaSil/ } \\
\text { solids }\end{array}$ & $\begin{array}{l}\text { Water/ } \\
\text { solids }\end{array}$ & $\begin{array}{l}\text { BB/FA } \\
\text { ratio }\end{array}$ \\
\hline 1/4B & 64 & 16 & 20 & 0.41 & 0.025 & $1 / 4$ \\
2/3B & 48 & 32 & 20 & 0.41 & 0.030 & $2 / 3$ \\
3/2B & 32 & 48 & 20 & 0.41 & 0.045 & $3 / 2$ \\
4/1B & 16 & 64 & 20 & 0.41 & 0.050 & $4 / 1$ \\
\hline
\end{tabular}

these geopolymeric materials have been processed for studying the potential use of geopolymers as waste immobilizing agents.

Table 5 shows the results of the leaching test of BB, FA and EAFD according to EN 12457-4 [12] and the limits stated by the European landfill regulations (EULFD) [33] for inert (I), non-hazardous $(\mathrm{NH})$ and hazardous $(\mathrm{H})$ waste. From the results showed in Table 5, BB is considered a non-hazardous waste (Mo limit), FA is classified as inert waste, and EAFD exceeds the hazardous waste limits for Mo.

Table 6 shows the geopolymer compositions manufactured in the present work. The effect of different FA/ $\mathrm{BB}$ ratios has been analysed. In all the compositions, the EAFD content and NaSil/solids ratio were kept constant. The water content was adjusted to achieve the same workability in all the mixtures. With the mass obtained, moulds were filled and compacted. Finally, the pastes were vibrated for $5 \mathrm{~min}$ in order to release bubbles. During the curing period, all the samples were placed at room temperature.

Figure 8 shows the compressive strength results obtained for the different compositions of geopolymers after 7, 14 and 28 days of curing. The addition of bottom ash decreased the compressive strength, which increased with the time in all cases.

The results of TCLP leaching test [13] of geopolymer specimens and the limits imposed [13] by EPA are shown in Table 7. From the results obtained, all the compositions analysed did not meet the limits for $\mathrm{Pb}$ and $\mathrm{Cd}$, although they complied with the limits for the other heavy metals. Regarding the amount of $\mathrm{BB}$ used in the formulations, the metal concentrations in the leachate remained nearly within the same range in all the different compositions. However,
Fig. 8 Evolution of compressive strength versus time

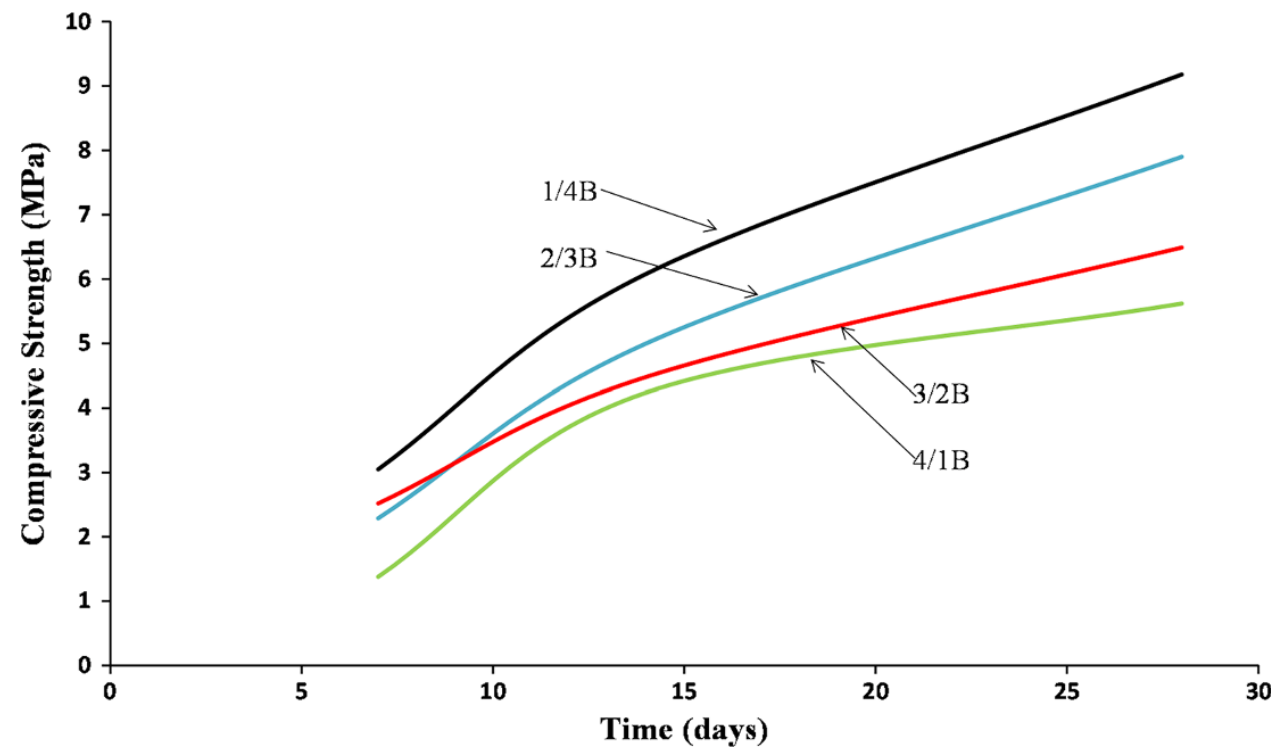


Table 7 Leaching test TCLP results: concentration of heavy metals $(\mathrm{mg} / \mathrm{L})$

\begin{tabular}{lccccl}
\hline & $1 / 4 \mathrm{~B}$ & $2 / 3 \mathrm{~B}$ & $3 / 2 \mathrm{~B}$ & $4 / 1 \mathrm{~B}$ & EPA limits \\
\hline $\mathrm{Hg}$ & $\leq 0.002$ & $\leq 0.002$ & $\leq 0.002$ & $\leq 0.002$ & 0.2 \\
$\mathrm{Se}$ & 0.049 & 0.051 & 0.039 & 0.040 & 1 \\
$\mathrm{~Pb}$ & 19.6 & 27.0 & 30.2 & 39.1 & 5 \\
$\mathrm{Ba}$ & 0.74 & 0.61 & 1.28 & 1.05 & 100 \\
$\mathrm{Cd}$ & 2.11 & 1.83 & 2.44 & 1.85 & 1 \\
$\mathrm{Cr}$ & 0.18 & 0.20 & 0.24 & 0.21 & 5 \\
$\mathrm{As}$ & 0.036 & 0.018 & 0.010 & $\leq 0.003$ & 5 \\
\hline
\end{tabular}

Table 8 Concentration $(\mathrm{mg} / \mathrm{kg})$ in leachate according to EN 12457-4 of geopolymers

\begin{tabular}{lcccclllr}
\hline & $\begin{array}{l}1 / 4 \mathrm{~B} \\
(\mathrm{mg} / \mathrm{kg})\end{array}$ & $\begin{array}{l}2 / 3 \mathrm{~B} \\
(\mathrm{mg} / \mathrm{kg})\end{array}$ & $\begin{array}{l}3 / 2 \mathrm{~B} \\
(\mathrm{mg} / \mathrm{kg})\end{array}$ & $\begin{array}{l}4 / 1 \mathrm{~B} \\
(\mathrm{mg} / \mathrm{kg})\end{array}$ & \multicolumn{3}{l}{$\begin{array}{l}\text { Limits EULFD } \\
(\mathrm{mg} / \mathrm{kg})\end{array}$} \\
\cline { 6 - 8 } & & & & & & $\mathrm{I}$ & $\mathrm{NH}$ & $\mathrm{H}$ \\
\hline $\mathrm{Hg}$ & $\leq 0.01$ & $\leq 0.01$ & $\leq 0.01$ & $\leq 0.01$ & 0.01 & 0.2 & 2 \\
$\mathrm{Se}$ & 0.80 & 0.83 & 0.95 & 0.73 & 0.1 & 0.5 & 7 \\
$\mathrm{~Pb}$ & 5.5 & 4.6 & 3.4 & 2.4 & 0.5 & 10 & 50 \\
$\mathrm{Ba}$ & 0.17 & 0.13 & 0.09 & 0.11 & 20 & 100 & 300 \\
$\mathrm{Cd}$ & $\leq 0.01$ & $\leq 0.01$ & $\leq 0.01$ & $\leq 0.01$ & 0.04 & 1 & 5 \\
$\mathrm{Sb}$ & $\leq 0.05$ & 0.13 & $\leq 0.05$ & $\leq 0.05$ & 0.06 & 0.7 & 5 \\
$\mathrm{Cr}$ & 23.4 & 21.6 & 20.4 & 16.6 & 0.5 & 10 & 70 \\
$\mathrm{As}$ & 3.92 & 3.51 & 2.61 & 1.41 & 0.5 & 2 & 25 \\
$\mathrm{Mo}$ & 23.1 & 22.8 & 24.1 & 24.3 & 0.5 & 10 & 30 \\
$\mathrm{Ni}$ & $\leq 0.01$ & 0.04 & 0.06 & 0.04 & 0.4 & 10 & 40 \\
$\mathrm{Zn}$ & 4.31 & 4.21 & 5.01 & 3.21 & 4 & 50 & 200 \\
$\mathrm{Cu}$ & 0.13 & 0.12 & 0.24 & 0.13 & 2 & 50 & 10 \\
\hline
\end{tabular}

the concentration of $\mathrm{Pb}, \mathrm{Zn}$ and $\mathrm{Cu}$ increased when the proportion of BB increased, and decreased the leaching of some oxyanions, such as As, probably due to the reducing character of the bottom ash.

Table 8 shows the results obtained for the geopolymer specimens studied in this work according to EN 12457-4 [12]. The results are compared with the limits stated by the European directive on landfills (EULFD) [33]. When the concentrations are compared with the limits of the EULFD they showed great variability between the concentrations of the heavy metals analysed. Regarding $\mathrm{Hg}, \mathrm{Ba}, \mathrm{Cd}, \mathrm{Ni}$ and $\mathrm{Cu}$, the solids could be disposed at inert landfills; according to $\mathrm{Pb}, \mathrm{Sb}$ and $\mathrm{Zn}$, could be at non-hazardous landfills, whereas the As, Cr, Se and Mo only met the limit of hazardous waste.

Regarding the proportion of bottom ash in the geopolymer mixtures, the concentrations of heavy metals were similar in all the compositions, although it should be noted that using higher amount of bottom ash reduced the content of $\mathrm{Pb}, \mathrm{As}$ and $\mathrm{Cr}$ in the leachate.
Table 9 Composition of different HRB mixtures

\begin{tabular}{lll}
\hline & FA/activating solution & $\mathrm{NaOH} / \mathrm{Na}_{2} \mathrm{SiO}_{3}$ \\
\hline $\mathrm{G}-0$ & 2.0 & 0 \\
$\mathrm{G}-1 / 3$ & 2.0 & 0.33 \\
$\mathrm{G}-1 / 2$ & 2.0 & 0.5 \\
$\mathrm{G}-1$ & 2.0 & 1 \\
$\mathrm{G}-2$ & 2.0 & 2 \\
\hline
\end{tabular}

Table 10 Physical properties of HRBs

\begin{tabular}{llllll}
\hline & $\begin{array}{l}\text { Density } \\
\left(\mathrm{kg} / \mathrm{m}^{3}\right)\end{array}$ & $\begin{array}{l}\text { Moisture } \\
(\%)\end{array}$ & $\begin{array}{l}\text { Water } \\
\text { absorption } \\
(\%)\end{array}$ & $\begin{array}{l}\text { Volume } \\
\text { stability } \\
(\mathrm{mm})\end{array}$ & $\begin{array}{l}\text { Initial setting } \\
\text { time (min) }\end{array}$ \\
\hline $\mathrm{G}-0$ & $1,762.5$ & 4.92 & 15.75 & 2.0 & 160 \\
$\mathrm{G}-1 / 3$ & $1,784.2$ & 5.61 & 15.63 & 1.5 & 165 \\
$\mathrm{G}-1 / 2$ & $1,838.3$ & 6.54 & 13.67 & 1.0 & 180 \\
$\mathrm{G}-1$ & $1,861.4$ & 7.32 & 12.27 & 2.0 & 210 \\
$\mathrm{G}-2$ & $1,876.0$ & 7.87 & 11.15 & 1.5 & 240 \\
\hline
\end{tabular}

Utilization of geopolymers mainly composed of fly ashes as hydraulic road binders

Table 9 shows the compositions made throughout the present work. The effect of different $\mathrm{NaOH} / \mathrm{Na}_{2} \mathrm{SiO}_{3}$ ratios has been analysed. In all the compositions, the fly ash to alkali activator (FA/AA) ratio was 2 and was kept fixed for all the mixtures. With the mass obtained, moulds were filled and compacted. Finally, the pastes were vibrated for $5 \mathrm{~min}$ in order to release bubbles. The influence of curing temperature on the mechanical properties of the HRBs was also analysed. All the samples were placed either at room temperature $\left(20^{\circ} \mathrm{C}\right)$ or in the oven at $60^{\circ} \mathrm{C}$.

The results obtained regarding the physical properties of the HRBs are shown in Table 10. The results show that the density and the moisture content of the pastes increased with the $\mathrm{NaOH} / \mathrm{Na}_{2} \mathrm{SiO}_{3}$ ratio in all the cases. On the other hand, the water absorption decreased with this ratio due to the higher density. The results of volume stability show that these geopolymers have no problems of expansion during the test ( $<30 \mathrm{~mm}$ specified in EN 13282-2 [34]). According to the initial setting time results, all the HRBs analysed would be included within the standard HRB Normal Hardening (EN 13282-2), because the initial setting times were higher than 150 min. This parameter increased with $\mathrm{NaOH} / \mathrm{Na}_{2} \mathrm{SiO}_{3}$ ratio because the mix of $\mathrm{NaOH}$ and sodium silicate solutions lowers the viscosity of the activating solution; therefore, the system needs more time for setting [35].

The particle size distribution of the fly ash was showed in Fig. 1. As it can be seen, the FA are $<15 \%$ (weight) bigger than $90 \mu \mathrm{m}$, as required by the standard EN 13282-2 [34]. The Standard requires that the content of $\mathrm{SO}_{3}$ (see 


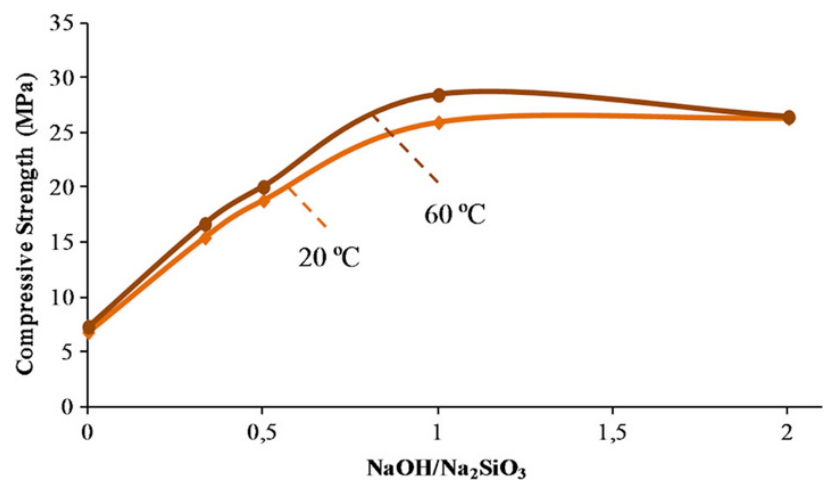

Fig. 9 Compressive strength of hydraulic road binders

Table 11 Classification of HRBs

\begin{tabular}{lll}
\hline & $\begin{array}{l}\text { Compressive strength } \\
\text { (56 days) }\end{array}$ & $\begin{array}{l}\text { EN 13282-2 } \\
\text { classification }\end{array}$ \\
\hline EN 13282-2 specifications & $\geq 5-\leq 22.5$ & $\mathrm{~N} 1$ \\
& $\geq 12.5-\leq 32.5$ & $\mathrm{~N} 2$ \\
& $\geq 22.5-\leq 42.5$ & $\mathrm{~N} 3$ \\
& $\geq 32.5-\leq 52.5$ & $\mathrm{~N} 4$ \\
G-0 & 6.8 & $\mathrm{~N} 1$ \\
G-1/3 & 15.4 & $\mathrm{~N} 2$ \\
G-1/2 & 18.8 & $\mathrm{~N} 2$ \\
G-1 & 25.9 & $\mathrm{N3}$ \\
G-2 & 26.3 & $\mathrm{N3}$
\end{tabular}

The classification of different compositions analyzed in this work according to compressive strength specifications of EN 13282-2 are in italics

Table 1) must be lower than $4 \%$, so the fly ash can be used as constituent of HRBs.

The compressive strength was measured after 56 days of curing. The mechanical strength was measured for all $\mathrm{NaOH} /$ $\mathrm{Na}_{2} \mathrm{SiO}_{3}$ ratios and at two different curing temperatures.

Figure 9 shows that the compressive strength increased with the $\mathrm{NaOH} / \mathrm{Na}_{2} \mathrm{SiO}_{3}$ ratio until it reached the maximum value for $\mathrm{NaOH} / \mathrm{Na}_{2} \mathrm{SiO}_{3}=1$. This is rather unexpected since the literature indicates that a low $\mathrm{NaOH} / \mathrm{Na}_{\mathrm{s}} \mathrm{SiO}_{3}$ ratio provides a higher compressive strength [36]. The variation of the $\mathrm{NaOH} / \mathrm{Na}_{2} \mathrm{SiO}_{3}$ ratio affects the $\mathrm{pH}$ conditions and thus would have some effects on the strength development [37]. The curing temperature had no influence on the compressive strength obtained after 56 days of curing. According with EN 13282-2, the HRBs mixtures developed could be classified in the categories presented in Table 11 .

\section{Conclusions}

The results obtained in this study show that even higher ratios of replacement ( $>40 \%$ ) of ashes may be used as an effective alternative to those commonly used in manufacturing construction materials:

- The bottom ash addition to ceramic bricks properties decreased the density and compressive strength, and an increase in the water absorption of the final products. An increase of the firing temperature improves their mechanical and physical properties.

- Crushed bottom ash might be potentially recycled as pozzolanic material in cement production since bottom ashes meet all the requirements established by the European standards. The compressive strength of the bottom ash-based mixtures allows the compositions $5-15,25$ and $35 \%$ of bottom ash to be classified in class $52.5,43.5$ and 32.5 , respectively.

- Stabilisation of a hazardous waste using bottom and fly ash-based geopolymers is possible, and after the solidification process the final material containing hazardous wastes can be deposed in a non-hazardous landfill.

- Utilization of geopolymers mainly composed of fly ashes as HRBs is a good option, because all the physical, chemical and mechanical requirements of European standards are satisfied.

Acknowledgments We acknowledge the financial support for this research by the Spanish Ministry of Science and Technology with European FEDER funds, under GEOPOL project (CTM2010-19917).

Conflict of interests The authors declare that they have no competing interests.

Authors' contributions YL carried out the stabilisation/solidification study and participated in its design and coordination and helped to draft the manuscript. CA carried out the bricks and concrete studies. AC carried out the leaching test and hydraulic road binders study. CL conceived of the study and drafted the manuscript. LVA coordinated and helped to draft the manuscript. CFP participated in its design and helped to draft the manuscript. All authors read and approved the final manuscript.

Open Access This article is distributed under the terms of the Creative Commons Attribution License which permits any use, distribution, and reproduction in any medium, provided the original author(s) and the source are credited.

\section{References}

1. ECOBA, European Coal Combustion Products Association. Utilisation of coal combustion products. http://www.ecoba.com/ evjm,media/ccps/ecoba_statistics_2009.pdf

2. EN 197-1: cement. Part 1: composition, specifications and conformity criteria for common cements (2011)

3. Davidovits, J., Comrie, D.: Long term durability of hazardous toxic and nuclear waste disposal. In: Proceedings of Geopolymer, vol. 88. Compiegne, France (1988)

4. Van Jaarsveld, S., Van Deventer, J.S.J., Lorenzen, L.: The potential use of geopolymer materials to immobilize toxic metals. Miner. Eng. 10, 659-669 (1997) 
5. Cheng, T.W., Chiu, J.P.: Fire-resistant geopolymer produced by granulated blast furnace slag. Miner. Eng. 16, 205-210 (2003)

6. ASTM E 605-93: standard test methods for thickness and density of sprayed fire-resistive material (SFRM) applied to structural members. ASTM International (2011)

7. UNE 67-027-84: Ladrillos de arcilla cocida. Determinación de la absorción de agua (1984)

8. EN 12859: gypsum blocks-definitions, requirements and test methods (2012)

9. EN 196-3: methods of testing cement. Part 3: determination of setting times and soundness (2009)

10. EN 196-1: methods of testing cement. Part 1: determination of the strength (2005)

11. ASTM C348-08: standard test method for flexural strength of hydraulic-cement mortars. ASTM International (2008)

12. EN 12457-4: characterization of waste: leaching. Compliance test for leaching of granular waste material and sludges. Part 2: one stage batch test at a liquid to solid ratio of $10 \mathrm{l} / \mathrm{kg}$ for materials with particle size below $10 \mathrm{~mm}$ (without or with size reduction) (2003)

13. US EPA: test methods for evaluating solid wastes, toxicity characteristic leaching procedure (TCLP). Method 1311 SW-846, 3rd edn. Environmental Protection Agency, Washington DC (1986)

14. Güeto, Morales: J: Tecnología de los materiales cerámicos. Díaz de Santos, Madrid (2005)

15. Ramos Verdejo, G.: Desarrollo de materiales cerámicos compuestos fundamentalmente por cenizas volantes, Proyecto fin de carrera, Escuela Técnica Superior de Ingeniería, Universidad de Sevilla (2012)

16. Cheng, T.W., Chen, Y.S.: Characterisation of glass ceramics made from incinerator fly ash. Ceram. Int. 30, 343-349 (2004)

17. Lingling, X., Wei, G., Tao, W., Nanru, Y.: Study on fired bricks with replacing clay by fly ash in high volume ratio. Constr. Build. Mater. 19, 243-247 (2004)

18. Loryuenyoung, V., Panyachai, T., Kaewsimork, K., Siritai, C.: Effects of recycled glass substitution on the physical and mechanical properties of clay bricks. Waste Manag. 29, 2717-2721 (2009)

19. Long Lin, K.: Feasibility study of using brick made from municipal solid waste incinerator fly ash slag. J. Hazard. Mater. B137, 1810-1816 (2006)

20. Kurama, H., Kaya, M.: Usage of coal combustion bottom ash in concrete mixture. Constr. Build. Mater. 22, 1922-1928 (2008)

21. Kute, S., Deodhar, S.V.: Effect of fly ash and temperature on properties of burnt clay bricks. J. Civ. Eng. 84, 82-85 (2003)

22. EN 450-1. Fly ash for concrete. Part 1: definitions, specifications and conformity criteria (2013)

23. Cengiz, D.A.: Strength properties of high-volume fly ash roller compacted and workable concrete, and influence of curing conditions. Cement Concrete Res. 35, 1112-1121 (2005)

24. Guanghong, S., Jianping, Z., Gin, L., Feihu, L.: Utilization of fly ash coming from a CFBC boiler co-firing coal and petroleum coke in Portland cement. Fuel 86, 2625-2631 (2007)

25. Cheriaf, M., Cavalcante Rocha, J., Péra, J.: Pozzolanic properties of pulverised coal combustion bottom ash. Cement Concrete Res. 29, 1387-1391 (1999)

26. Canpolat, F., Yilmaz, K., Kose, M.M., Sumer, M., Yurdusev, M.A.: Use of zeolite, coal bottom ash and fly ash as replacement materials in cement production. Cement Concrete Res. 34, 731-735 (2004)
27. Sumer, M.: Compressive strength and sulphate resistance properties of concretes containing class $\mathrm{F}$ and class $\mathrm{C}$ fly ashes. Cement Concrete Res. 34, 531-536 (2012)

28. Weng, C.H., Lin, D.F., Chiang, P.C.: Utilisation of sludge as brick materials. Adv. Environ. Res. 7, 585-679 (2003)

29. Kuder, K., Lehman, D., Berman, J., Hannesson, G., Shogrenm, R.: Mechanical properties of self-consolidating concrete blended with high volumes of fly ash and slag. Constr. Build. Mater. 34, 285-295 (2012)

30. Siddique, R.: Compressive strength, water absorption, sorptivity, abrasion resistance, and permeability of self-compacting concrete containing coal bottom ash. Constr. Build. Mater. 47, 1444-1450 (2013)

31. Argiz, C., Menéndez, E., Sanjuán, M.A.: Effect of mixes made of coal bottom ash and fly ash on the mechanical strength and porosity of Portland cement. Mater Constr. 63, 49-64 (2013)

32. UNE 83414: Adiciones al hormigón. Ceniza Volante. Recomendaciones generales para la adición de cenizas volantes a los hormigones fabricados con cemento tipo I (1990)

33. Council Directive 1999/31/EC of 26 April 1999 on the landfill of waste (EULFD) (1999)

34. EN 13282-2: hydraulic road binders-Part 2: normal hardening hydraulic road binders-composition, specifications and conformity criteria (2010)

35. Davidovits, J.: Properties of geopolymers cements. In: Proceedings First International Conference on Alkaline Cements and Concretes, pp. 131-49 (1994)

36. Al Bakri, M.: Effect of $\mathrm{Na}_{\mathrm{s}} \mathrm{SiO}_{3} / \mathrm{NaOH}$ ratios and $\mathrm{NaOH}$ molarities on compressive strength of fly-ash-based geopolymer. ACI Mater. J. 109, 503-508 (2012)

37. Chindaprasirt, P., Chareerat, T., Sirivivatnanon, V.: Workability and strength of coarse high calcium fly ash geopolymer. Cement Concrete Com. 29, 224-229 (2007)

Yolanda Luna is an assistant professor in in the Chemical and Environmental Department of University of Seville, her research interest is waste management and wastewater treatment.

Celia G. Arenas is a Ph.D. scholar in the Chemical and Environmental Department of University of Seville.

Ana Cornejo is a Ph.D. scholar in the Chemical and Environmental Department of University of Seville, Spain.

Carlos Leiva is an assistant professor in the Chemical and Environmental Department of University of Seville, Spain, his research interests are solid and air waste management.

Luis F. Vilches is an associate professor in Chemical and Environmental Department of University of Seville, his research interests are water and wastewater treatment, solid waste management.

Constantino Fernández-Pereira is a professor in Chemical and Environmental Department of University of Seville, his research interests are water, wastewater treatment and solid waste management. 